\title{
Biochemical and hematological profiles of a wild population of the nose-horned viper Vipera ammodytes (Serpentes: Viperidae) during autumn, with a morphological assessment of blood cells
}

\author{
Duje Lisičić, Domagoj Đikić, Vesna Benković, Anica Horvat Knežević, Nada Oršolić and Zoran Tadić
}

\begin{abstract}
Background: Hematological and biochemical analyses of blood can be of great importance for studying the biology of species and determining the health status of animals in both the wild and captivity. In order to determine baseline ranges for the nose-horned viper Vipera ammodytes, we determined the blood cell morphology and measured 20 hematological and 5 biochemical variables from the blood samples taken from 31 (17 males and 14 females) healthy specimens of nose-horned viper caught in the wild at the beginning of autumn.

Results: Most of the measured parameters and blood cell morphology were similar to those reported for other reptile species. The males showed a significantly higher eosinophil count and higher mean cell hemoglobin (MCH) and $\mathrm{MCH}$ concentration values, while the females had a significantly higher mature erythrocyte count. The erythrocyte differential counts showed balanced hematopoiesis in this part of the annual cycle.

Conclusions: We suggest that these results can be used as a baseline for determining hematological values and blood cell morphology for $V$. ammodytes, as well as in further studies including monitoring and determination of the health status of this species, especially of animals kept in captivity for antiserum production. This is the most complete report regarding hematological parameters of this endangered snake species.
\end{abstract}

Keywords: Blood cells; Hematology; Blood biochemistry; Reptile; Vipera ammodytes; Snake

\section{Background}

The nose-horned viper Vipera ammodytes is a Eurasian viper species characterized by the distinct fleshy horn at the tip of its snout. This species inhabits dry, rocky habitats with some vegetation and good exposure to the sun (Arnold and Ovenden 2002). V. ammodytes is listed in the Bern Convention on the Conservation of European Wildlife and Natural Habitats (Anonymous 1982) and is also protected in Croatia (Anonymous 2011). Because of the expanding urbanization, many snake populations in Croatia have become effectively suburban. Such populations are endangered by many factors, and active monitoring and measures, both ecological and biomedical, may be needed to preserve them. Although several

\footnotetext{
* Correspondence: dujelisicic@gmail.com

Department of Animal Physiology, Division of Biology, Faculty of Science, University of Zagreb, Rooseveltov trg 6, Zagreb HR-10 000, Croatia
}

studies dealt with the phylogeography and ecology of this species (Tomović and Džukić 2003; Tomović 2006; Crnobrnja-Isailović et al. 2007; Ursenbacher et al. 2008), physiological/ecophysiological studies of this species are almost nonexistent. Only Frye (1991) in his monograph cited one reference value for a $V$. ammodytes erythrocyte count made by Babudieri in 1930 .

Hematological and biochemical analyses of blood can be of great importance in studying the biology of a species and determining the health or reproductive status of animals in both the wild and captivity (Canfield 1998; Campbell and Ellis 2007; Tumkiratiwong et al. 2012). Reptiles, being poikilothermic vertebrates, can be used as nonstandard bioindicators for assaying natural populations to investigate the presence of pollutants and mutagens in the environment (Matson et al. 2005; Strunjak-Perović et al. 2010). Moreover, by analyzing the hematology and 
blood biochemistry of reptiles, we can get a picture of the hemoparasite load in natural populations. Since animals can mount immune responses to hemoparasites, and the level of immunity can be linked to fitness-related life history traits mediating sexual selection (Lopez and Martin 2005; Bouma et al. 2007), hematological and biomedical studies can also reveal important aspects of reptilian behavioral ecology. In addition, being poikilothermic, reptiles have more diverse immunological responses than those found in higher vertebrates, making reptiles an ideal model for studying the development and adaptations of the immunological system in vertebrates (Siroski et al. 2009; Siroski et al. 2010).

Hematological studies and the establishment of baseline ranges for $V$. ammodytes would be useful for understanding general aspects of this species' ecology and may give us information on the health status of individual snakes or entire populations in the wild. Such studies may also be useful for captive populations, as $V$. ammodytes is usually kept as a source of venom for antiserum production. Therefore, in this paper, we report data for hematological and blood chemical profiles, and also describe the morphology of circulating blood cells of adult $V$. ammodytes caught in the wild. This is the most complete report of hematological parameters for this snake species. An understanding of its hematology may indirectly improve husbandry techniques and prolong animal life-spans in captivity, reducing the need for frequent collection of this endangered species from the wild.

\section{Methods}

\section{Snakes}

The study was conducted with 31 (17 males and 14 females) healthy adult $V$. ammodytes caught in the wild during the beginning of autumn in 2005 and 2011. The snakes were caught in the vicinity of the town of Zabok $\left(46^{\circ} 09^{\prime} 58^{\prime \prime} \mathrm{N}, 15^{\circ} 55^{\prime} 08^{\prime \prime} \mathrm{E}\right)$ in the Hrvatsko Zagorje region of northern Croatia. The snakes were transferred to the laboratory and maintained in individual plastic terrariums (Geo Flat Large, Ferplast, Castelgomberto, Italy) for $48 \mathrm{~h}$, before the start of the experiment, in order to calm them and reduce stress prior to handling. The photoperiod was identical to the natural one, and the temperature followed natural fluctuations, with day temperatures reaching $30^{\circ} \mathrm{C}$ and night temperatures falling to around $20^{\circ} \mathrm{C}$. Water was provided ad libitum in each terrarium.

\section{Blood collection and analysis of hematological and biochemical parameters}

The blood samples were taken from the caudal vein (Campbell 2006) using a 5-mL plastic syringe with a 0.45 -gauge needle. Special care was taken not to puncture the caudal lymph vessels during blood collection. If this occurred (a drop of clear fluid would appear in the syringe at the start of collection), the sampling was repeated on a different part of the tail (Campbell and Ellis 2007). Blood smears (three slides per individual snake) which were made immediately after blood collection to avoid thrombocyte clumping and morphological changes were air dried and stained with May-Grünwald-Giemsa stain. The rest of the collected blood was quickly separated into two Eppendorf tubes coated with sodium heparin: one for hematological parameter determination, and the other for plasma biochemical analyses.

Total red blood cell (RBC) and total white blood cell (WBC) counts were manually calculated using NattHerrick's solution (Frye 1991) and a hemocytometer chamber. For each snake, three heparinized microhematocrit capillary tubes (ABX Micros 60 Biomerieux, Montpellier, France) filled with whole blood and centrifuged for $2 \mathrm{~min}$ at $13,800 \times g$ (StatSpin VT, Westwood, MA, USA) were used to determine the packed cell volume (PCV). The hemoglobin concentration was determined using the cyanomethaemoglobin method. The mean cell volume $(\mathrm{MCV})$, mean cell hemoglobin $(\mathrm{MCH})$, and mean cell hemoglobin concentration $(\mathrm{MCHC})$ were calculated by the method described in Campbell and Ellis (2007).

Blood smears were used for the differential relative and absolute $\mathrm{RBC}$ and $\mathrm{WBC}$ counts following the nomenclature proposed by Campbell (2006). The differential RBC count was done by counting 1,500 erythrocytes per slide (three slides per snake) which were classified as immature erythrocytes, mature erythrocytes, and other erythrocyte types, which included the sum of micro- and macrocytes, erythroplastids, pyknotic erythrocytes, and erythrocytes with intracytoplasmic inclusions (Frye 1991). For the differential WBC count, 200 leukocytes per slide (three slides per snake) were counted and classified as lymphocytes, azurophils, heterophils, eosinophils, and basophils. Total thrombocyte (TT) counts were calculated for 200 leucocytes found in the visual field. In order to obtain size characteristics of the different blood cells types, 80 cells of each cell type for each individual snake were photographed under $\times 1,000$ magnification with a digital camera connected to a Zeiss Axiovert microscope (Carl Zeiss, Oberkochen, Germany). The sizes of the cells and their nuclei were analyzed with the Carl Zeiss AxioVision 3.1 program.

For the biochemical analyses, immediately after blood collection, the Eppendorf tubes with the blood samples were centrifuged for $90 \mathrm{~s}$ at $12,000 \times g$ (StatSpin VT). The obtained plasma sample was used to determine glucose, total protein, cholesterol, uric acid, and triglycerides, which were measured using standard commercial kits (BioAssay Systems, Hayward, CA, USA).

The erythrocyte sedimentation rate (ESR) was measured in graduated tubes filled with heparinized blood 
and placed vertically. The height of the blood cell column was recorded after 1,2 , and $24 \mathrm{~h}$.

The care and use of the experimental animals complied with animal welfare laws, guidelines, and policies of Croatia. All the procedures were approved by the University of Zagreb ethical committee permit no. 04/2007.

\section{Statistical analysis}

Hematological and plasma biochemical values were analyzed for statistical differences $(p<0.05)$ between sexes. The data were tested for normality and homoscedasticity by Shapiro-Wilk's $W$ test and were found not to be normally distributed. Consequently, a nonparametric Mann-Whitney $U$ test was used in STATISTICA software (StatSoft, Tulsa, OK, USA). The values for each parameter are provided as the median and range (minimum and maximum) for each sex.

\section{Results}

All snakes were adults (snout-vent length of $56.21 \pm$ $5.27 \mathrm{~cm}$, weight of $105.53 \pm 22.51 \mathrm{~g}$ ). In addition, all snakes were given a complete physical examination. The females were neither gravid nor postpartum at the time of the experiment. The number of snakes used was adjusted according to the recommendation of the State
Directorate of Nature Protection so that it did not put pressure on the natural population, but at the same time, provided acceptable results for achieving the goals of the study.

\section{Hematology and blood cell morphology}

Ranges for RBC parameters are given in Table 1. Females showed significantly higher values than males for the mature erythrocyte count. In addition, females showed significantly lower $\mathrm{MCH}$ and $\mathrm{MCHC}$ values. Other hematological parameters were not influenced by sex. The highest levels of variation were observed for the total RBC count, mature erythrocyte count, and MCV in females and the $\mathrm{MCHC}$ in males.

Size characteristics of the erythrocyte types found in $V$. ammodytes blood are given in Table 2. The mature erythrocytes were oval, with slightly acidophilic cytoplasm and a strongly basophilic centrally located ellipsoidal nucleus, which was more elongated than the erythrocyte itself. The immature erythrocytes were smaller than the mature cells, with more rounded basophilic cytoplasm and a more rounded, centrally located nucleus (Figure 1a). Occasionally, other erythrocyte types were observed on the smears that were counted under the same category. These consisted of pyknotic erythrocytes (erythrocytes

Table 1 Red blood cell (RBC) range and biochemical parameters for adult Vipera ammodytes

\begin{tabular}{|c|c|c|c|c|c|c|c|c|}
\hline \multirow[t]{2}{*}{ Parameter (units) } & \multicolumn{3}{|c|}{ Males } & \multicolumn{3}{|c|}{ Females } & \multicolumn{2}{|c|}{ Mann-Whitney } \\
\hline & $\bar{n}$ & Median & Range & $n$ & Median & Range & $U$ value & $p$ value \\
\hline Total RBC (×1011/L) & 17 & 7.88 & $3.88-9.38$ & 14 & 9.0 & $4.88-14.1$ & 73.5 & 0.0705 \\
\hline Mature erythrocytes (\%) & 17 & 98.55 & $92.73-99.8$ & 14 & 98.61 & $97.03-99.46$ & 100 & 0.4683 \\
\hline Mature erythrocytes $\left(\times 10^{11} / \mathrm{L}\right)$ & 17 & 7.51 & $3.73-9.29$ & 14 & 9.18 & $4.77-13.1$ & 64 & 0.0290 \\
\hline Immature erythrocytes (\%) & 17 & 0 & $0-5$ & 14 & 0.09 & $0-1.24$ & 111.5 & 0.7692 \\
\hline Immature erythrocytes $\left(\times 10^{9} / \mathrm{L}\right)$ & 17 & 0 & $0-40.3$ & 14 & 0.67 & $0-8.37$ & 115.5 & 0.8911 \\
\hline Other erythrocyte types (\%) & 17 & 0.47 & $0-3.33$ & 14 & 0.9 & $0.23-2.94$ & 84 & 0.1733 \\
\hline Other erythrocyte types $\left(\times 10^{9} / \mathrm{L}\right)$ & 17 & 3.56 & $0-20.3$ & 14 & 7.05 & $2.35-41.4$ & 80 & 0.1278 \\
\hline Hemoglobin (g/L) & 11 & 80.39 & $64.16-86.16$ & 10 & 69.3 & $52.87-81.25$ & 35 & 0.1734 \\
\hline PCV (\%) & 17 & 26 & $17-34$ & 14 & 29 & $17-38$ & 84 & 0.1733 \\
\hline MCV (fL) & 17 & 363.94 & $266.67-438.71$ & 14 & 300 & $179-646$ & 76 & 0.0919 \\
\hline $\mathrm{MCH}(\mathrm{pg})$ & 11 & 102.09 & 74.48-177.1 & 10 & 71.77 & $55.16-129.76$ & 14 & 0.0028 \\
\hline $\mathrm{MCHC}(\mathrm{g} / \mathrm{dL})$ & 11 & 286.64 & $188.7-415.92$ & 10 & 244.69 & $179.62-280.17$ & 15 & 0.0037 \\
\hline $\mathrm{ESR} / 1 \mathrm{~h}(\mathrm{~mm} / \mathrm{h})$ & 10 & 4 & $2-7$ & 9 & 4 & $3-11$ & 40.5 & 0.7200 \\
\hline $\mathrm{ESR} / 2 \mathrm{~h}(\mathrm{~mm} / \mathrm{h})$ & 10 & 11 & $7-22$ & 9 & 10 & $6-45$ & 43.0 & 0.9000 \\
\hline $\mathrm{ESR} / 24 \mathrm{~h}(\mathrm{~mm} / \mathrm{h})$ & 10 & 113 & $109-127$ & 9 & 114 & $69-148$ & 44.5 & 0.9700 \\
\hline Glucose (mg/dL) & 10 & 73.99 & $52.35-128.02$ & 9 & 109.5 & $27.45-168.45$ & 33 & 0.3500 \\
\hline Total protein $(\mathrm{g} / \mathrm{dL})$ & 10 & 5.33 & $4.58-5.81$ & 9 & 5.41 & $5.36-7.85$ & 30 & 0.2400 \\
\hline Cholesterol (mg/dL) & 10 & 272.05 & $169.84-313.97$ & 9 & 295.5 & $212.57-462.63$ & 39 & 0.6600 \\
\hline Uric acid (mg/dL) & 10 & 3.96 & $3.51-6.2$ & 9 & 5.19 & $3.38-9.1$ & 36 & 0.4900 \\
\hline Triglycerides (mmol/L) & 10 & 1.18 & $0.6-1.7$ & 9 & 0.87 & $0.77-1.21$ & 30 & 0.2400 \\
\hline
\end{tabular}

PCV packed cell volume, $M C V$ mean cell volume, $M C H$ mean cell hemoglobin, $M C H C M C H$ concentration, ESR erythrocyte sedimentation rate. 
Table 2 Size characteristics of the erythrocytes and thrombocytes from Vipera ammodytes blood

\begin{tabular}{|c|c|c|c|c|}
\hline \multirow[t]{2}{*}{ Erythrocyte type } & \multicolumn{2}{|c|}{ Cell size $(\mu \mathrm{m})$} & \multicolumn{2}{|c|}{ Nucleus size $(\mu \mathrm{m})$} \\
\hline & Length & Width & Length & Width \\
\hline \multirow[t]{2}{*}{ Mature erythrocytes } & $18.36 \pm 1.21$ & $12.65 \pm 0.67$ & $8.04 \pm 0.73$ & $4.69 \pm 0.44$ \\
\hline & $(15.93-21.28)$ & $(11.06-13.78)$ & $(6.56-9.67)$ & $(3.84-5.80)$ \\
\hline \multirow[t]{2}{*}{ Immature erythrocytes } & $15.47 \pm 1.51$ & $11.73 \pm 1.19$ & $7.91 \pm 0.99$ & $6.57 \pm 1.1$ \\
\hline & $(11.46-18.37)$ & $(9.51-14.85)$ & $(5.42-10.49)$ & $(4.49-9.24)$ \\
\hline \multirow[t]{2}{*}{ Microcytes } & $13.37 \pm 4.08$ & $8.19 \pm 1.52$ & $5.38 \pm 1.33$ & $4.99 \pm 0.77$ \\
\hline & $(9.73-17.78)$ & $(6.45-9.30)$ & $(4.14-6.79)$ & $(4.14-5.64)$ \\
\hline \multirow[t]{2}{*}{ Macrocytes } & $24.82 \pm 1.75$ & $14.72 \pm 1.26$ & $10.54 \pm 1.46$ & $6.53 \pm 0.87$ \\
\hline & $(22.44-27.19)$ & $(12.44-15.95)$ & $(7.55-12.15)$ & $(5.32-7.42)$ \\
\hline \multirow[t]{2}{*}{ Erythroplastids } & $10.61 \pm 5.4$ & $7.7 \pm 1.6$ & $7.7 \pm 1.7$ & $7.16 \pm 1.2$ \\
\hline & $(6.54-18.94)$ & $(5.67-10.12)$ & $(5.68-11.06)$ & $(5.68-9.76)$ \\
\hline \multirow[t]{2}{*}{ Pyknotic erythrocytes } & $18.40 \pm 2.24$ & $12.06 \pm 1.84$ & $4.76 \pm 0.81$ & $4.41 \pm 0.46$ \\
\hline & $(13.19-22.94)$ & $(7.87-14.99)$ & $(3.84-6.34)$ & $(3.84-5.56)$ \\
\hline \multirow[t]{2}{*}{ Elongated thrombocytes } & $12.97 \pm 2.32$ & $7.91 \pm 1.12$ & $8.88 \pm 0.93$ & $5.91 \pm 0.61$ \\
\hline & $(3.74-18.77)$ & $(5.43-12.66)$ & $(6.25-11.03)$ & $(4.95-7.79)$ \\
\hline \multirow[t]{2}{*}{ Rounded thrombocytes } & $10.41 \pm 1.24$ & $9.07 \pm 0.95$ & $7.63 \pm 0.98$ & $6.44 \pm 0.73$ \\
\hline & $(8.55-13.33)$ & $(7.55-12.03)$ & $(6.1-9.95)$ & $(5.39-7.86)$ \\
\hline
\end{tabular}

Values are given as the mean \pm SD (range). SD standard deviation.

with a small, rounded intensely stained nucleus), microcytes (very small erythrocytes), macrocytes (unusually large erythrocytes), erythroplastids (erythrocyte cells without a nucleus), and erythrocytes with unidentified intracytoplasmic vacuoles. In a few cases, the erythrocytes were observed to be undergoing mitosis.

The total and differential WBC counts and TT count are given in Table 3. Males showed significantly higher eosinophil counts than females, while other measured parameters were not influenced by sex. Lymphocytes were the most abundant of the WBC types, followed by azurophils, while basophils were only rarely seen. The highest variation was recorded for the total WBC and thrombocyte counts. The thrombocyte-to-leukocyte ratio was 1.5 .

The morphometric measurements of various types of leukocytes are given in Table 4. Lymphocytes had a wider range of sizes than any other blood cell type. They mostly had irregularly shaped basophilic cytoplasm and a large nucleus (Figure 1b). Azurophils were spherical to slightly oval cells with a rounded eccentrically located nucleus. The blue-stained cytoplasm contained many small, azurophilic granules (Figure 1c). Azurophils possibly contained vacuoles in the cytoplasm, ranging in number from one to eight. Eosinophils were the largest leukocytes found in the smears. They were rounded cells with a peripherally placed, weakly basophilic nucleus and cytoplasm rich with acidophilic granules (Figure 1d). Heterophils were rounded cells with cytoplasm containing granules that were not stained at all, or occasionally were slightly acidophilic or basophilic. The nucleus was eccentrically located, partly ellipsoidal, and basophilic (Figure 1e). In basophils, the eccentrically positioned nucleus was identified as a violet patch hidden in the cytoplasm full of basophilic granules (Figure 1f). Thrombocytes were ellipsoidal cells containing slightly basophilic bluishgray cytoplasm and a strongly basophilic centrally located nucleus; however, these could be oval, with a similar nucleus surrounded by irregularly formed cytoplasm (Figure 1b).

\section{Plasma biochemistry}

Ranges established for the biochemical parameters in the blood of adult $V$. ammodytes are given in Table 1. There were no significant differences related to sex for the measured biochemical parameters. The greatest variations were observed for glucose and uric acid, while the protein concentration showed relatively stable values.

\section{Discussion}

Published hematologic profiles for reptiles often fail to include information that may influence the hemogram, such as the gender, age, season, physiological status, or the precise methodology (Campbell 2006). In order to obtain very precise ranges, we sampled adult individuals collected during autumn. By choosing autumn, we also avoided the mating season and gravidity of females. Unfortunately, we were unable to obtain enough blood from each snake for a complete analysis of all of the parameters without affecting either the health of the 

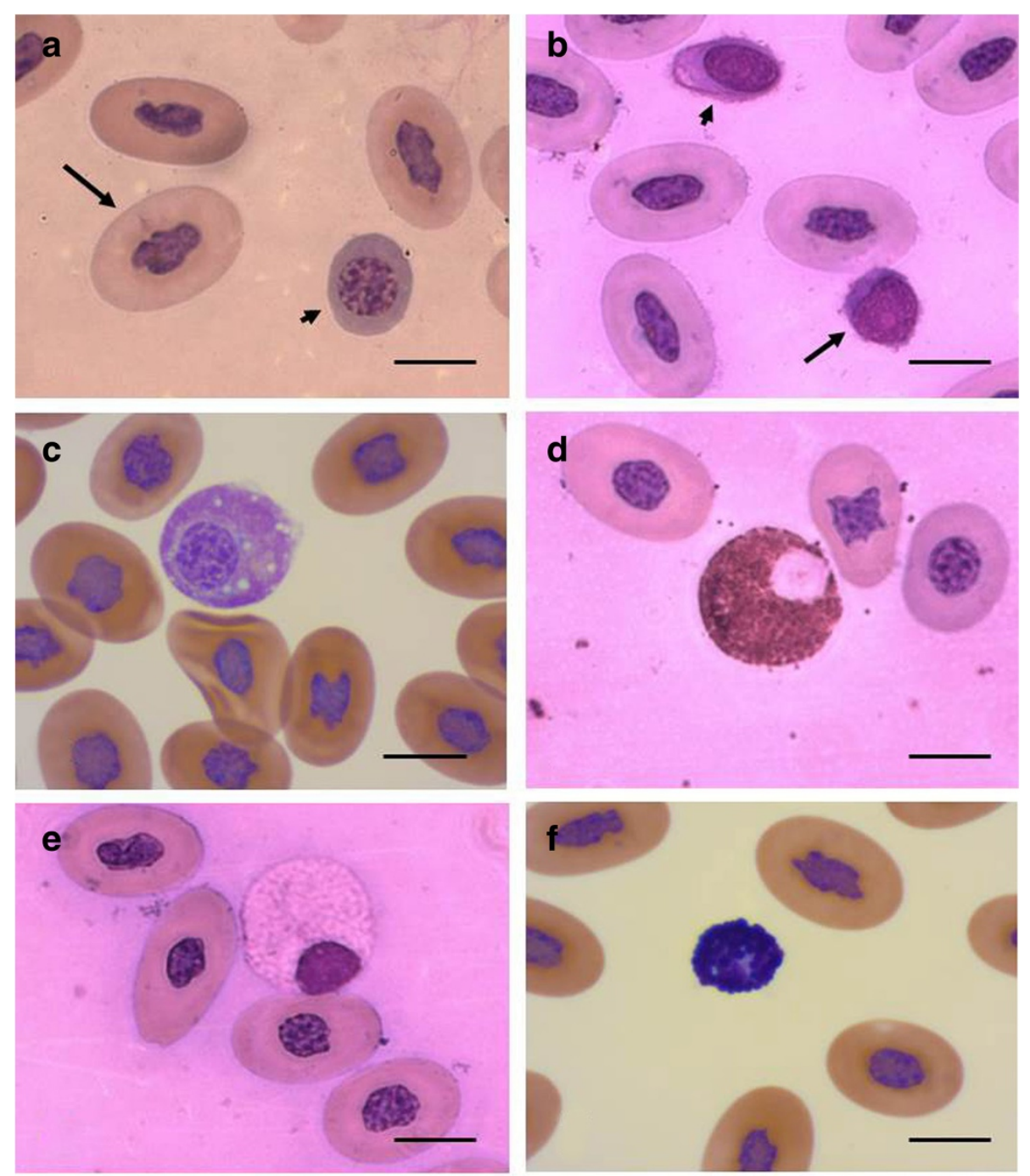

Figure 1 Blood cells of Vipera ammodytes ( $\times 1,000$ magnification). Mature erythrocyte (a, long arrow), immature erythrocyte (a, short arrow), lymphocyte (b, long arrow), azurophil (c), eosinophil (d), heterophil (e), basophil (f), thrombocytes (b, short arrow) stained with May-Grünwald-Giemsa stain. Bars $=10 \mu \mathrm{m}$.

animals or the results of the analysis itself. In cases where we lacked a sufficient blood volume sample for a complete analysis, we focused on blood cell parameters (see biochemical and some hematological parameters in Table 1). Special care was taken to avoid lymph dilution during blood sampling. Blood dilution with lymph during blood sampling in reptiles may be a big problem, since lymph vessels are usually situated in the proximity of blood vessels. Lymph is similar to plasma in composition, but not in the percentages of its constituents. So, lymph collected with a blood sample can alter the blood biochemical values and lower the blood cell counts due to a dilution effect (López-Oliviera et al. 2003; Campbell 2006). In case of lymph vessel puncture, lymph fluid appears in the syringe prior to the appearance of blood, and the sample must be discarded and the procedure repeated from a slightly different place (Campbell and Ellis 2007). The probability of lymph contamination varies with the site of puncture. A study done on chameleons showed that venipuncture from a tail vein is relatively safe from lymph contamination (Cuadrado et al. 2003). Additional checking may be done after the blood analysis, by comparing variances of some blood biochemical parameters that are affected by lymph dilution, like total protein and uric acid (Cuadrado et al. 2003). If these parameters show great variations among individuals, this may indicate that lymph dilution occurred in some samples. In our study, the total protein and uric acid showed stable values, proving that the blood had not been contaminated by lymph dilution.

The hematocrit (PCV) of $V$. ammodytes was in the range reported for other reptiles, as was the hemoglobin 
Table 3 Total thrombocyte (TT) and white blood cell (WBC) range for adult Vipera ammodytes

\begin{tabular}{|c|c|c|c|c|c|c|c|c|}
\hline \multirow[t]{2}{*}{ Parameter (units) } & \multicolumn{3}{|c|}{ Males } & \multicolumn{3}{|c|}{ Females } & \multicolumn{2}{|c|}{ Mann-Whitney } \\
\hline & $n$ & Median & Range & $n$ & Median & Range & $U$ value & $p$ value \\
\hline$\pi\left(\times 10^{9} / \mathrm{L}\right)$ & 17 & 24.83 & $10.8-71.23$ & 14 & 18.26 & $7-64.21$ & 90 & 0.2621 \\
\hline WBC $\left(\times 10^{9} / \mathrm{L}\right)$ & 17 & 13.3 & $4.71-34.53$ & 14 & 14.8 & $5.77-34.2$ & 111 & 0.7692 \\
\hline Lymphocytes (\%) & 17 & 45.54 & $19.61-65.17$ & 14 & 54.6 & $35.32-67.14$ & 76 & 0.0919 \\
\hline Lymphocytes $\left(\times 10^{9} / \mathrm{L}\right)$ & 17 & 3.49 & $2.5-19.83$ & 14 & 6.51 & $0.38-17.7$ & 83 & 0.1609 \\
\hline Azurophils (\%) & 17 & 29.29 & $6.9-50.79$ & 14 & 22.9 & $11.44-42.21$ & 103 & 0.5437 \\
\hline Azurophils $\left(\times 10^{9} / \mathrm{L}\right)$ & 17 & 5.44 & $0.28-12.06$ & 14 & 3.18 & $0.9-11.05$ & 111 & 0.7692 \\
\hline Heterophils (\%) & 17 & 12.38 & $4.52-48.02$ & 14 & 13.02 & $7.46-50.24$ & 100 & 0.4683 \\
\hline Heterophils $\left(\times 10^{9} / \mathrm{L}\right)$ & 17 & 1.31 & $0.23-16.43$ & 14 & 1.93 & $0.52-10.68$ & 96 & 0.3771 \\
\hline Eosinophils (\%) & 17 & 10.05 & $4.98-32.35$ & 14 & 4.17 & $1.48-21.7$ & 53 & 0.0079 \\
\hline Eosinophils $\left(\times 10^{9} / \mathrm{L}\right)$ & 17 & 1.12 & $0.5-5.76$ & 14 & 0.51 & $0.21-5.95$ & 61 & 0.0209 \\
\hline Basophils (\%) & 17 & 0 & $0-4.83$ & 14 & 0.48 & $0-4.48$ & 111 & 0.7692 \\
\hline Basophils $\left(\times 10^{9} / \mathrm{L}\right)$ & 17 & 0 & $0-1.31$ & 14 & 0.11 & $0-0.97$ & 112 & 0.7993 \\
\hline
\end{tabular}

concentration (Dessauer 1970; Dutton and Taylor 2003). The total RBC count showed a slightly higher value than those reported for captive Bothrops species (Troiano et al. 2000), but lower than those reported for captive Crotalus durissus terrificus (Troiano et al. 1997), with values mostly similar to those of the king cobra (Ophiophagus hannah, Salakij et al. 2002) or some lizards (Sodeinde and Ogunjobi 1994). The MCV revealed that the erythrocytes of $V$. ammodytes had a typical volume for a reptile, reaching an upper value reported among snakes and lizards (Frye 1991). Relatively low $\mathrm{MCH}$ and $\mathrm{MCHC}$ values indicated that erythrocytes had lower 'packing' of hemoglobin since most reptiles have large erythrocytes, but lower cellularity, compared to endotherms (Canfield 1998). It is known that RBC-related parameters, due to captive husbandry and veterinary management, differ between captive and wild populations. Also, the parasite load in captive populations is absent or negligible (Rangel-Mendoza et al. 2009). In a study done on the king cobra, a wild population showed significantly lower values for most RBC-related parameters, compared to the captive population (Salakij et al.
2002). This must be taken into account if data from this study are used for assessing the health status of captive populations of $V$. ammodytes. Hematological parameters may be useful for assessing the general health status of the animal, particularly dehydration or anemia (Dessauer 1970; Campbell 2006). In some reptiles, males have a higher PCV, hemoglobin concentration, and total RBC count than females (Duguy 1970; Wojtaszek 1991). In contrast, a study on green iguanas showed that females had higher PCV, hemoglobin concentration, and $\mathrm{MCHC}$ values than males (Harr et al. 2001). In our study, females showed higher mature erythrocyte counts and lower $\mathrm{MCH}$ and $\mathrm{MCHC}$ values than males. It may be that females compensate for a lower hemoglobin concentration in erythrocytes by a higher mature erythrocyte count, a fact that could passed unnoticed if only total RBC values were observed. This may be induced by gravidity, since females may supply their offspring with iron from their own body reserves. The ESR is a parameter rarely determined in reptiles. We obtained results that are very similar to those reported by Wojtaszek (1991) (mean ESR for a grass snake of $5.56 \mathrm{~mm} / \mathrm{h}$ vs. a

Table 4 Size characteristics of different leukocytes from Vipera ammodytes blood (in micrometers)

\begin{tabular}{|c|c|c|c|}
\hline \multirow{2}{*}{$\begin{array}{l}\text { Leukocyte } \\
\text { type }\end{array}$} & \multirow[t]{2}{*}{ Cell size } & \multicolumn{2}{|c|}{ Nucleus size } \\
\hline & & Length & Width \\
\hline Lymphocytes & $10.15 \pm 2.46(6.08-18.83)$ & $8.81 \pm 1.46(6.08-14.02)$ & $7.27 \pm 1.07(4.5-10.33)$ \\
\hline Azurophils & $15.54 \pm 3.71(7.32-22.99)$ & $9.41 \pm 0.85(7.01-12.5)$ & $7.81 \pm 0.72(5.31-10.49)$ \\
\hline Heterophils & $16.87 \pm 1.41(13.69-21.42)$ & $7.97 \pm 1.18(5.98-11.6)$ & $6.4 \pm 0.99(5.04-11.06)$ \\
\hline Eosinophils & $17.3 \pm 1.36(13.59-20.85)$ & $8.16 \pm 1.28(4.67-10.65)$ & $5.90 \pm 1.06(3.22-7.68)$ \\
\hline Basophils & $10.21 \pm 1.07(8.31-12.92)$ & $8.56 \pm 0.46(8.18-9.07)$ & $6.09 \pm 0.52(5.63-6.66)$ \\
\hline
\end{tabular}

Values are given as the mean \pm SD (range). SD standard deviation. 
mean ESR for the nose-horned viper of $5.88 \mathrm{~mm} / \mathrm{h}$ ). Because the ESR is rarely measured, its significance remains unknown.

The ratio between different erythrocyte types indicates normal erythropoiesis activity, but it may also be evidence of pathological changes. For example, a lack of a balance in the juvenile/mature erythrocyte ratio may indicate an ongoing disease (Campbell 2006; Oliveira-Junior et al. 2009). The total RBC count of $V$. ammodytes contained a high percentage of mature erythrocyte cells (99\%), although as much as 5\% of immature erythrocytes were present in some snakes (see Table 1). The reported low percentage of immature erythrocytes may indicate normal erythropoiesis activity for autumn in this species. A low percentage of other erythrocyte types in the blood of $V$. ammodytes was also reported for other reptile species (Frye 1991).

Large variations in the total $\mathrm{WBC}$ and TT counts were reported for $V$. ammodytes in this study, as well as for other reptiles, and are considered normal (Duguy 1970; Campbell and Ellis 2007). The mean total WBC count in $V$. ammodytes was similar to that reported for some other snake species (Troiano et al. 2000), but it was higher than those reported for pre- and posthibernating vipers held in captivity (Dutton and Taylor 2003). It is considered normal that wild populations have higher total WBC values than captive ones, probably due to elevated parasite infestations and also due to differences in ambient conditions between natural and captive environments (Salakij et al. 2002; Rangel-Mendoza et al. 2009). Some lizards show high values of the total WBC count (Sodeinde and Ogunjobi 1994), which is near the maximum value recorded for $V$. ammodytes. Wojtaszek (1991) reported TT count in Natrix natrix ranging from 32 to $34 \times 10^{9} / \mathrm{L}$, depending on the sex, similar to results of the present study. The thrombocyte/leukocyte ratio was approximately 2 for $N$. natrix, compared to 1.5 for $V$. ammodytes. In $V$. ammodytes, the range in the TT count was wider than that reported for $N$. natrix. Other reptiles, however, may greatly differ. The rainbow lizard Agama agama (Sodeinde and Ogunjobi 1994) has a relatively low TT count that ranges from 5.6 to $8.8 \times 10^{9} / \mathrm{L}$, and leukocytes up to seven or nine times higher than thrombocytes in same unit of volume.

In the total WBC count of $V$. ammodytes, lymphocytes were on average the most common leukocytes (about $50 \%$ of total leukocytes), which is in agreement with findings for other vipers (Troiano et al. 1997; Dutton and Taylor 2003). Azurophils were the second most common leukocyte type observed. Azurophils were reported in reptilian blood by some authors (Troiano et al. 2000), but not by others (Wojtaszek 1991). Blood of $V$. ammodytes had a high azurophil count compared to that of other reptiles (Campbell and Ellis 2007), but was similar to that reported for a wild population of king cobra (Salakij et al. 2002). Both the lymphocyte and azurophil counts showed relatively high variations in $V$. ammodytes blood. Although heterophils showed the highest range of values compared to other leukocyte types reported in this study, the average heterophil count fell within the range reported for other reptiles (Campbell and Ellis 2007), but fit data reported for wild king cobra (Salakij et al. 2002). The count of reptilian heterophils may be affected by some diseases or tissue injury (Campbell 2006). In our study, there were no toxic heterophils (the appearance of which is associated with diseases such bacterial infections) observed in the smears. It may be that a high variation of the heterophil count and high variation of lymphocyte and azurophil counts may be associated with strictly individual factors, such as the susceptibility of an individual snake to stress, microorganisms in the environment, or some other intrinsic or extrinsic factor.

The percentage of basophils in $V$. ammodytes was lower than those reported for many other reptile species (Frye 1991; Troiano et al. 1997). However, in some reptiles, the number of these cells was within the range observed in this study (Knotková et al. 2002; Salakij et al. 2002). Since basophils are associated with viral or parasitic infections (Campbell and Ellis 2007), the low number reported in our study may indicate an absence of such infections in the studied population during autumn.

The percentage of eosinophils was within the range reported for other reptiles (Campbell and Ellis 2007). In our study, males had a significantly higher eosinophil count than females. This difference may have been related to the different physiology of the sexes. Although it was reported that the eosinophil number rises during parasite infestations (Saint Girons 1970; Campbell 2006), this might not be an explanation in our study, since the basophils disproved such an infection. It might be more likely that the sexes had different fluctuations in the eosinophil count in relation to seasonal changes. Further study is needed to clarify the mechanism of such physiological differences between the sexes and its potential adaptive value.

In the present study, we reported sizes and shapes of different types of blood cells in $V$. ammodytes blood. Since the morphology of different blood cell lines may be affected by various intrinsic and extrinsic factors, reporting morphological characterization of normal blood cells in $V$. ammodytes blood may be of value for future clinical examinations.

The morphology of mature erythrocytes is typical of the form found in reptiles (Uğurtaş et al. 2003). There was greatest similarity to the erythrocytes observed in related snake species like Vipera aspis and Vipera berus (Frye 1991), although the erythrocytes in $V$. ammodytes 
were slightly larger. Immature erythrocytes and other erythrocyte types were also similar to those reported for other reptiles (Frye 1991; Canfield 1998). In general, the size and shape of thrombocytes and various types of leukocytes corresponded to those reported for other reptiles (Saint Girons 1970; Frye 1991). Basophils showed the slightest morphometric variations compared to other leukocyte types. Azurophils were proposed to be counted as monocytes in the recent literature since these two cell types show similar cytochemical properties. In our study, we named this leukocyte lineage azurophils, since most of the cells we observed showed azurophilic granules in the cytoplasm, a feature typical of snake hematology (Campbell and Ellis 2007).

The values of glucose, total protein, cholesterol, uric acid, and triglycerides (Table 1) were within the ranges reported for plasma biochemical values of other reptiles (Dessauer 1970; Dutton and Taylor 2003; Čož-Rakovac et al. 2011). Only the cholesterol concentration showed slightly lower values than those reported for other vipers. Considering the wide range of variability dependent on various external and internal factors, this slight variation is not unexpected (Campbell 2006). Although biochemical parameters showed no statistical differences between the sexes, recorded values were generally higher in females. It is known that there are differences in the biochemical status between males and females, but these are mainly related to the breeding season (Dessauer 1970; Hildago-Villa et al. 2007). In our study, the females may have given birth a few weeks before blood sampling, and the observed higher values might have been linked to this. Alternatively, males and females may have slightly different physiological and behavioral traits that generate differences in biochemical and hematological parameters.

We suggest that these results can be used as a baseline for determining hematological values and blood cell morphology for $V$. ammodytes. They can be used in further studies including monitoring and determination of the health status of this species, especially of animals kept in captivity for antiserum production. It is known that virtually all hematological parameters in reptiles are seasonally dynamic. This is a normal phenomenon since these animals may alter their body fluid composition to acclimatize to changing environmental conditions (Dessauer 1970; Duguy 1970; Campbell 2006). In addition, further analysis of seasonal dynamics of blood components and comparative studies on young animals and/or gravid females are needed to better understand the hematology of $V$. ammodytes.

\section{Conclusion}

In this study, we determined the blood cell morphology and measured 20 hematological and 5 biochemical variables from 31 (17 males and 14 females) healthy specimens of $V$. ammodytes caught in the wild at the beginning of autumn. To our knowledge, physiological/ecophysiological studies of this species are almost nonexistent. We suggest that the presented results can be used as a baseline for determining hematological values and blood cell morphology for $V$. ammodytes. They can be used in further studies including monitoring and determination of the health status of this species, especially of animals kept in captivity for antiserum production.

\section{Competing interests}

The authors declare that they have no competing interests.

\section{Authors' contributions}

$\mathrm{D} \ominus, \mathrm{AHK}, \mathrm{VB}$, and $\mathrm{NO}$ collected the animals, carried out the experiment, and participated in the statistical analysis. ZT conceived of the study and participated in the interpretation of the results. DL participated in the design and coordination of the study, interpreted the results, and drafted the manuscript. All authors read and approved the final manuscript.

\section{Acknowledgements}

This work was made possible through grant no. 119-0000000-1285 of the Ministry of Science, Education and Sport of the Republic of Croatia to Zoran Tadić. We thank the State Directorate for the Nature Protection of Ministry of Culture of the Republic of Croatia for the collecting permit.

Received: 29 December 2012 Accepted: 15 March 2013 Published: 23 September 2013

\section{References}

Anonymous (1982) Convention on the conservation of European wildlife and natural habitats. Council of Europe. CETS no, Bern, Switzerland, p 104

Anonymous (2011) Nature Protection Act OG 70/05, 139/08, and 57/11; Ordinance on Proclamation of Wild Taxa as Protected and Strictly Protected OG 99/09. Croatian Parliament, Zagreb, Croatia (in Croatian)

Arnold EN, Ovenden D (2002) Field guide to the reptiles and amphibians of Britain and Europe, 2nd edn. Harper Collins, London, p 272

Bouma MJ, Smallridge CJ, Bull CM, Komdeur J (2007) Susceptibility to infection by a haemogregarine parasite and the impact of infection in the Australian sleepy lizard Tiliqua rugosa. Parasitol Res 100:949-954

Campbell TW (2006) Clinical pathology of reptiles. In: Mader DR (ed) Reptile medicine and surgery. Saunders, Philadelphia, PA, pp 453-470

Campbell TW, Ellis CS (2007) Avian and exotic animal hematology and cytology, 3rd edn. Blackwell, Ames, IA

Canfield PJ (1998) Comparative cell morphology in the peripheral blood film from exotic and native animals. Aust Vet J 76:793-800

Čož-Rakovac R, Lisičić D, Šmuc T, Topić Popović N, Strunjak-Perović I, Jadan M, Tadić Z, Jug Dujaković J (2011) Classification modelling of physiological stages in captive Balkan whip snakes using blood biochemistry parameters. J Herpetol 45:525-529

Crnobrnja-Isailović J, Ajtić R, Tomović L (2007) Activity patterns of the sand viper (Vipera ammodytes) from the central Balkans. Amphib-Reptil 28:582-589

Cuadrado M, Molina-Prescott I, Flores L (2003) Comparison between tail and jugular venipuncture techniques for blood sample collection in common chameleons (Chamaeleo chamaeleon). Vet J 166:93-97

Dessauer HC (1970) Blood chemistry in reptiles: physiological and evolutionary aspects. In: Gans C, Parsons TS (eds) Biology of the Reptilia, vol 3. Academic, New York, pp 1-72

Duguy R (1970) Numbers of blood cells and their variations. In: Gans C, Parsons TS (eds) Biology of the Reptilia, vol 3. Academic, New York, pp 93-109

Dutton CJ, Taylor P (2003) A comparison between pre- and posthibernation morphometry, haematology, and blood chemistry in viperid snakes. J Zoo Wildl Med 34:53-58

Frye FL (1991) Hematology as applied to clinical reptile medicine. In: Frye FL (ed) Reptile care: an atlas of diseases and treatments. TFH, Neptune City, NJ, pp 209-279

Harr KE, Alleman AR, Dennis PM, Maxwell LK, Lock BA, Bennett RA, Jacobson ER (2001) Morphologic and cytochemical characteristics of blood cells and 
haematologic and plasma biochemical reference in green iguanas. J Am Vet Med Assoc 218:915-921

Hildago-Villa J, Díaz-Paniagua C, Pérez-Santigosa N, Plaza A, Camacho I, Recio F (2007) Hematologic and biochemical reference intervals of free-living Mediterranean pond turtles (Mauremis leprosa). J Wildl Dis 43:798-801

Knotková Z, Doubek J, Knotek Z, Hájková P (2002) Blood cell morphology and plasma biochemistry in Russian tortoises (Agrionemys horsfieldi). Acta Vet Brno 71:191-198

Lopez P, Martin J (2005) Female Iberian wall lizards prefer male scents that signal a better cell-mediated immune response. Biol Lett 1:404-406

López-Oliviera JR, Montané J, Marco I, Martínez-Silvestre A, Soler J, Lavín S (2003) Effect of venipuncture site on hematologic and serum biochemical parameters in marinated tortoise (Testudo marginata). J Wildl Dis 39:830-836

Matson CW, Palatnikov G, Islamzadeh A, Mcdonald TJ, Autenrieth RL, Donnelly

KC, Bickham JW (2005) Chromosomal damage in two species of aquatic turtles (Emys orbicularis and Mauremys caspica) inhabiting contaminated sites in Azerbaijan. Ecotoxicology 14:513-525

Oliveira-Júnior AA, Tavares-Dias M, Marcon JL (2009) Biochemical and hematological reference ranges for Amazon freshwater turtle, hematological reference ranges for Amazon freshwater turtle, Podocnemis expansa (Reptilia: Pelomedusidae), with morphologic assessment of blood cells. Res Vet Sci 86:146-151

Rangel-Mendoza J, Weber M, Zenteno-Ruiz CE, López-Luna MA, Barba-Macías E (2009) Hematology and serum biochemistry comparison in wild and captive Central American river turtles (Dermatemys mawii) in Tabasco. Mexico Res Vet Sci 87:313-318

Saint Girons MC (1970) Morphology of the circulating blood cells. In: Gans C, Parsons TS (eds) Biology of the Reptilia, vol 3. Academic, New York, pp 73-91

Salakij C, Salakij J, Apibal S, Narkkong NA, Chanhome L, Rochanapat N (2002) Haematology, morphology, cytochemical staining, and ultrastructural characteristics of blood cells in king cobras (Ophiophagus hannah). Vet Clin Pathol 31:116-126

Siroski PA, Piña Cl, Larriera A, Merchant ME, Di Conza J (2009) Plasma activity of the broad-snouted caiman (Caiman latirostris). Zool Stud 48:238-242

Siroski PA, Merchant M, Marcó MVP, Piña Cl, Ortega HH (2010) Characterization of the serum complement activity of the broad-snouted caiman Caiman latirostris (Crocodilia: Alligatoridae). Zool Stud 49:64-70

Sodeinde OA, Ogunjobi AA (1994) Haematological values of the rainbow lizard Agama agama L. Herpetol J 4:86-90

Strunjak-Perović I, Lisičić D, Čoz-Rakovac R, Topić Popović N, Jadan M, Benković V, Tadić Z (2010) Evaluation of micronucleus and erythrocytic nuclear abnormalities in Balkan whip snake Hierophis gemonensis. Ecotoxicology 19:1460-1465

Tomović L (2006) Systematics of the nose-horned viper (Vipera ammodytes, Linnaeus, 1758). Herpetol J 16:191-201

Tomović L, Džukić G (2003) Geographic variability and taxonomy of the nosehorned viper, Vipera ammodytes (L. 1758), in the central and eastern parts of the Balkans: a multivariate study. Amphib-Reptil 24:359-377

Troiano JC, Vidal JC, Gould J, Gould E (1997) Haematological reference intervals of the South American rattlesnake (Crotalus durissus terrificus, Laurenti, 1768) in captivity. Compar Haematol Int 1:109-112

Troiano JC, Vidal JC, Gould EF, Heker J, Gould J, Vogt AU, Simoncini C, Amantini E, De Roodt A (2000) Haematological values of some Bothrops species (Ophidia - Crotalidae) in captivity. J Venom Anim Toxins 6:194-204., Available at: http://www.scielo.br/scielo.php?pid=s0104$79302000000200005 \&$ script=sci_arttext. Accessed 17 June 2010

Tumkiratiwong P, Meesuk W, Chanhome L, Aowphol A (2012) Reproductive patterns of captive male and female monocled cobra, Naja kaouthia (Lesson, 1831). Zool Stud 51:692-700

Uğurtaş IH, Senviç M, Yildirimhan HS (2003) Erythrocyte size and morphology of some tortoises and turtles from Turkey. Zool Stud 42:173-178
Ursenbacher S, Schweiger S, Tomović L, Crnobrnja-Isailović J, Fumagalli L, Mayer W (2008) Molecular phylogeography of the nose-horned viper (Vipera ammodytes, Linnaeus (1758)): evidence for high genetic diversity and multiple refugia in the Balkan Peninsula. Mol Phylogenet Evol 46:1116-1128

Wojtaszek JS (1991) Haematology of the grass snake Natrix natrix L. Compar Biochem Physiol Part A 100:805-812

doi:10.1186/1810-522X-52-11

Cite this article as: Lisičić et al: Biochemical and hematological profiles of a wild population of the nose-horned viper Vipera ammodytes (Serpentes: Viperidae) during autumn, with a morphological assessment of blood cells. Zoological Studies 2013 52:11.

\section{Submit your manuscript to a SpringerOpen ${ }^{\odot}$ journal and benefit from:}

- Convenient online submission

- Rigorous peer review

- Immediate publication on acceptance

- Open access: articles freely available online

High visibility within the field

- Retaining the copyright to your article

Submit your next manuscript at $\gg$ springeropen.com 